\title{
IDENTIFIKASI KEANEKARAGAMAN HAYATI DAN PEMETAAN BAWAH TANAH KAMPUS TERPADU UNIVERSITAS MUHAMMADIYAH PALANGKARAYA SEBAGAI MEDIA OBJEK PEMBELAJARAN
}

\author{
NURUL HIKMAH KARTINI \& INDAH SARI DEWI \\ Dosen Pada Fakultas Keguruan dan IImu Pendidikan Universitas Muhammadiyah Palangkaraya
}

\begin{abstract}
ABSTRAK
Pembelajaran inovatif selain dengan model, strategi, dan metode bervariasi, perlu juga pendekatan. Rendahnya pemahaman konsep dasar IPA melatarbelakangi peneliti untuk membuat media pembelajaran untuk identifikasi keanekaragaman hayati dan lapisan bawah permukaan bumi berupa pemetaan lapisan bawah tanah. Kurangnya informasi penelitian terdahulu mengenai penelitian di Kampus Terpadu UM Palangkaraya di Jl. Anggrek-Mahir Mahar membuat peneliti berusaha mengaitkan antara pendekatan lingkungan wilayah Kampus Terpadu UM Pembelajaran dengan capaian akhir berupa media objek pembelajaran IPA. Metode penelitian ini dimulai kajian teori awal mengenai pembelajaran IPA dilanjutkan survey lapangan. Pengamatan di lapangan akan meneliti cakupan wilayah seluas $1 \mathrm{Ha}$ yang teridentifikasi memiliki keanekaragaman hayati yang lebih tinggi dibandingkan lainnya. Setelah penetapan titik plot maka akuisisi dilakukan dengan 2 (dua) tahapan yaitu identifikasi keanekaragaman hayati dengan pengambilan sampel flora dan fauna yang ada pada titik plot. Tahap selanjutnya akuisisi pemetaan lapisan bawah tanah dengan menggunakan metode Potensial Diri dengan porous pot tembaga dan larutan $\mathrm{CuSO}_{4}$. Setelah akuisisi, dilanjutkan analisa data kedua tahapan tersebut. Keanekaragaman hayati berupa jenis flora dan fauna serta peta kontur lapisan dituangkan dalam media objek pembelajaran. Harapan di masa mendatang, peneliti dapat melanjutkan pemetaan atas permukaan dan bawah permukaan tanah dari Kampus Terpadu UM Palangkaraya secara keseluruhan seluas $20 \mathrm{Ha}$.
\end{abstract}

Keywords: Identifikasi keanekaragaman hayati, pemetaan bawah tanah metode SP, media objek pembelajaran

\section{PENDAHULUAN}

Konsep pembelajaran IPA mengutamakan keaktifan siswa membangun pengetahuannya sendiri, membandingkan informasi baru dengan pemahaman yang telah dimiliki, dan menggunakan semua pengetahuan atau pengalaman untuk belajar melalui perbedaanperbedaan yang ada pada pengetahuan baru dan lama untuk mencapai pemahaman baru. Hal ini menunjukkan adanya perubahan paradigma pendidikan, yaitu perubahan dari paradigma behavioristik menjadi paradigma konstruktivistik. Strategi pembelajaran konstruktivistik sudah banyak disosialisasikan dan diintegrasikan ke dalam kurikulum-kurikulum terbaru. Namun, kenyataan kegiatan pembelajaran di lingkungan sekolah tidaklah demikian. Pemilihan suatu pendekatan dan metode tertentu harus disesuaikan dengan tujuan pembelajaran dan sifat materi yang akan menjadi objek pembelajaran.

Berlangsungnya proses pembelajaran tidak terlepas dengan lingkungan sekitar. Pembelajaran dengan pendekatan lingkungan menghapus kejenuhan dan menciptakan peserta didik yang cinta lingkungan. Berdasarkan teori belajar, melalui pendekatan lingkungan pembelajaran menjadi bermakna. Konsep-konsep IPA dan lingkungan sekitar dapat dengan mudah dikuasai melalui pengamatan pada situasi yang konkret.

Berbagai usaha untuk memperoleh pembelajaran yang bermutu sudah dilaksanakan, diantaranya dengan penggunaan berbagai model, 
strategi dengan berbagai macam pendekatan. Berdasarkan observasi di Universitas Muhammadiyah Palangkaraya Program Studi Pendidikan Guru Sekolah Dasar (PGSD) menunjukkan bahwa sebagian mahasiswa kesulitan mengaplikasikan konsep mata pelajaran sains disaat mereka PPL dan Skripsi. Harapan pendidikan yang termasuk pada tujuan umum dari UM Palangkaraya diantaranya adalah "Terwujudnya pendidikan yang menghasilkan lulusan yang berkepribadian Islam, menguasai ilmu pengetahuan, teknologi, seni dan memiliki jiwa kewirausahaan melalui pengembangan Green Islamic Campus".

Dari uraian diatas, peneliti tertarik untuk mengadakan penelitian yang melibatkan mahasiswa yang mengambil mata kuliah IImu Kealaman Dasar untuk mengaplikasikan teori yang didapat melalui pendekatan lingkungan. Tidak hanya segi keilmuan biologi tapi juga segi keilmuan fisika.

Mata pelajaran IPA yang ada di Sekolah Dasar mencakup segi keilmuan Biologi dan Fisika. Pentingnya penelitian untuk mengidentifikasi keanekaragaman hayati sebagai aplikasi keilmuan IPA yang diperoleh di perguruan tinggi. Setelah teridentifikasi dan terpetakan maka data-data tersebut akan dituangkan dalam sebuah media pembelajaran IPA.

\section{METODE PENELITIAN}

Penelitian ini akan dilakukan di dua tempat. Akusisi data dilakukan di Kampus Terpadu UM Palangkaraya di Jl, Anggrek-Mahir Mahir Kecamatan Jekan Raya, Kota Palangkaraya. Sedangkan analisis data dilakukan di Kampus I
UM Palangkaraya JI. RTA Milono Km 1,5 Palangkaraya, Kalimantan Tengah.

Penelitian direncanakan melalui 4 tahap yaitu: 1) Persiapan survey lapangan; 2) Pengidentifikasian Keanekaragaman Hayati; 3) Akusisi data potensial diri; 4) Analisis Data; 5) Pembuatan Media Objek.

\section{Tahap 1. Persiapan}

Pada tahap ini yang dipersiapkan pertama kali adalah survey lapangan untuk menentukan titik plot penelitian sebesar $1 \mathrm{Ha}$. Dari observasi awal bisa diduga wilayah yang memiliki keanekaragaman hayati lebih tinggi dibandingkan wilayah lainnya. Setelah penentuan titik plot maka yang perlu dipersiapkan selanjutnya adalah rancangan akusisi data yang meliputi 2 (dua) tahap utama yaitu identifikasi keanekaragaman hayati dan pengukuran potensial diri dengan membuat daftar list barangbarang yang akan digunakan.

\section{Tahap 2. Identifikasi Keanekaragaman Hayati}

Untuk melakukan identifikasi keanekaragaman hayati, peneliti melibatkan beberapa mahsiswa yang mengambil Mata Kuliah IImu Kealaman Dasar untuk melakukan pengambilan data. Masing-masing mahasiswa akan mengidentifikasi luas wilayah ukuran $1 \times 1 \mathrm{~m}^{2}$ sebagai plot yang sudah ditetapkan oleh peneliti. Pembatas daerah yang digunakan berupa tali rafia ukuran $1 \mathrm{~m}^{2}$ yang dibuat bujur sangkar sesuai gambar. 


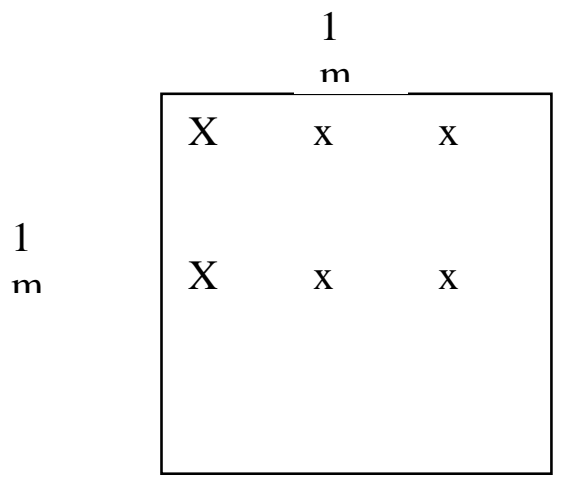

Gambar 1. Plot daerah identifikasi keanekaragaman hayati

Proses pengidentifikasian dimulai dengan mengamati tumbuhan dan hewan yang terdapat pada luas wilayah plot tersebut. Sampel tumbuhan dan sampel hewan dimasukkan ke botol plastik yang disediakan, kemudian akan diteliti keanekaragaman gen dan jenisnya. Dokumentasi juga penting untuk membantu analisa data.

\section{Tahap 3. Pengukuran Potensial diri}

Setelah pengambilan data untuk pengidentifikasian kenakeragaman, tahap berikutnya kita fokuskan untuk pemetaan bawah tanah dari luas wilayah yang diteliti yaitu $1 \mathrm{Ha}$ dengan menggunakan metode listrik potensial diri. Untuk melakukan pengukuran potensial diri di lapangan, perlu dilakukan tahap-tahap persiapan sebagai berikut:

1. Siapkan alat ukur potensial Digital Multimeter, elektroda porous pot 4 buah, larutan copper Sulphate, roll meter, roll kabel dan tabel pencatat data, serta alat komunikasi jika perlu.

2. Dari rancangan luasan yang akan diteliti kita tentukan titik referensi untuk penempatan salah satu elektroda yang menetap. Tentukan lintasan-lintasan pengukuran didalam luasan survey (survey design), yang nantinya akan digunakan untuk acuan pembagian kelompok pengukuran.

3. Kalibrasi Elektroda porous Pot

Elektroda porous pot terdiri dari batang tembaga dan tabung keramik dengan bagian bawah berpori, diisi dengan larutan $\mathrm{CuSO}_{4}$. Untuk mengkalibrasi elektroda porous pot yang telah diisi dengan larutan $\mathrm{CuSO}_{4}$ pada konsentrasi yang sama, masukkan satu pasang elektroda porous pot kedalam medium dengan jarak yang dekat (sekitar $10 \mathrm{~cm}$ ). Pada kondisi tersebut, ukur potensial dengan multimeter, dimana penunjukan harus lebih kecil atau sama dengan 2 milivolt. Apabila penunjukan ternyata lebih besar dari $2 \mathrm{mV}$, maka kedua elektroda porous pot tersebut harus dibersihkan terlebih dahulu, kemudian diisi kembali dengan larutan $\mathrm{CuSO}_{4}$ yang mempunyai konsentrasi yang sama.

4. Pada setiap lintasan, mempunyai paremeter koordinat titik awal pengukuran, azimuth dan interval jarak pengukuran $10 \mathrm{~m}$, yang kesemuanya dicatat dalam tabel pengumpulan data. Di lapangan, untuk melakukan survey metode SP digunakan 2 pasang elektroda porous pot dan dua multimeter. Satu pasang diletakkan secara permanen untuk mengukur variasi harian yang disebabkan arus telluric, yang kegunaannya untuk mengkoreksi data pengukuran. Sedang satu pasang yang lain digunakan untuk pengukuran sesuai dengan titik-titik pengukuran yang akan diukur. 


\begin{tabular}{|c|c|c|c|c|c|c|}
\hline $\mathrm{Y}$ & & $x$ & X & X & X & X \\
\hline$X$ & & $X$ & $\mathrm{X}$ & $\mathrm{X}$ & $\mathrm{X}$ & $\mathrm{X}$ \\
\hline$X$ & $X$ & $\mathrm{X}$ & $X$ & $X$ & $X$ & X \\
\hline$X$ & X & $X$ & $X$ & $X$ & $X$ & X \\
\hline
\end{tabular}

Gambar 2. Layout lintasan survey Potensial Diri

\section{Pengumpulan data}

Berdasarkan rancangan survey yang ada, pengukuran pada lintasan-lintasan telah ditetapkan pada peta. Titik awal perlu diketahui koordinatnya $(x, y)$ sehingga titik ukur yang lain pada lintaan yang sama dapat dihitung koordinatnya $(\mathrm{x}, \mathrm{y})$. hal tersebut berguna untuk pengolahan akhir dari bentuk kontur ekipotensial diri. Setiap titik diukur nilai tegangan yang terukur.

\section{Tahap 4. Analisis Data}

Data yang dianalisa dibagi kedalam 2 (dua) kelompok yaitu: data permukaan bumi dalam hal ini berupa identifikasi keanekaragaman hayati yang teramati oleh sampel-sampel yang diambil. Sampel tersebut diamati secara langsung dan juga dengan bantuan mikroskop untuk lebih teliti dalam penentuan spesiesnya secara detail. Sedangkan analisa data yang kedua adalah data bawah permukaan bumi berupa potensial yang terukur. Pada metode potensial diri, pengolahan data menghitung koordinat titik-titik ukur pada setiap lintasan, dari data paremeter lintasan seperti koordinat $(x, y)$ titik awal, azimuth dan interval jarak pengukuran. Dengan menggunakan excel, data-data dapat diolah dalam bentuk grafik, setelah dsmoothing baru kemudian dibuat peta kontur ekipotensial dengan bantuan software khusus pengolah data 2D metode listrik seperti res2div, dan lain-lain. Interpretasi penampang melintang kurva potensial diri akan menunjukkan informasi tentang kondisi bawah permukaan tanah tersebut.

\section{Tahap 5. Pembuatan Media Objek}

Tahap terakhir yaitu pembuatan media objek. Dari data identifikasi keanekaragaman hayati dan informasi lapisan struktur bawah permukaan bumi yang sudah ada akan dibuat sebuah media objek buatan berupa model. Output capaian akhir akan diperoleh 2 (dua) buah media objek pembelajaran.

\section{Tahap 1}

\section{PEMBAHASAN}

Pada tahap awal yang dilakukan pada penelitian ini adalah survey lapangan untuk menentukan titik plot penelitian sebesar $1 \mathrm{Ha}$. Dari observasi awal bisa diduga bahwa wilayah penelitian diduga mengandung mineral granit yang terlihat secara kasat mata yang tampak dipermukaan tanah. Keanekaragaman hayati flora yang teramati diantaranya yaitu ilalang, garunggang, akasia, dan lain-lain. Sedangkan keanekaragaman hayati fauna yang teramati diantaranya semut hitam, semut merah, lalat, cacing tanah, dan lain-lain.

\section{Tahap 2}

Setelah survey dilakukan, maka tahapan berikutnya adalah penentuan titik plot dengan jarak $1 \mathrm{~m}^{2}$ dan $10 \mathrm{~m}^{2}$. ada 100 titik yang akan diambil data terkait posisi dan potensialnya yang digunakan untuk pemetaan bawah tanah. Untuk identifikasi keanekaragaman hayati, peneliti melibatkan beberapa orang mahasiswa dalam 
pengambilan sampel flora dan fauna yang ada di lokasi penelitian.

\section{Tahap 3}

Pada tahapan ini dilakukan identifikasi penelitian untuk kenaekaragaman hayati, dengan plot $10 \mathrm{~m}^{2}$ diambil sample $1 \mathrm{~m}^{2}$. Sampel tumbuhan dan hewan yang teridentifikasi diambil dan akan dianalisa pada tahap berikutnya.

Tabel 2. Keanekaragaman Flora yang Teridentifikasi

\begin{tabular}{|c|c|c|}
\hline No & Nama / Nama Latin & Identifikasi \\
\hline 1 & $\begin{array}{l}\text { Karamunting } \\
\text { (Ochthocharis bornensis BI.) }\end{array}$ & $\begin{array}{l}\text { a. Tumbuh liar pada tempat yang mendapat sinar matahari } \\
\text { yang cukup } \\
\text { b. Ditemukan di ketinggian } 1.650 \mathrm{~m} \text { dari permukaan laut } \\
\text { c. Termasuk kelompok perdu, daun tunggal, bangun elips } \\
\text { memanjang sampai lonjong, duduk daun berhadapan } \\
\text { bersilang, permukaan daun berambut bila diraba terasa } \\
\text { kasar, pangkal daun membulat, tepi daun rata, ujung daun } \\
\text { meruncing. } \\
\text { d. Bunga majemuk berwarna ungu kemerah-merahan, } \\
\text { buahnya dapat dimakan serta memiliki biji berukuran kecil. } \\
\text { Menjelang matang, warna buah yang semula hijau menjadi } \\
\text { merah kecoklatan sampai hitam. }\end{array}$ \\
\hline 2 & $\begin{array}{l}\text { Rumput Meniran } \\
\text { (Phyllanthus urinaria L.) }\end{array}$ & $\begin{array}{l}\text { a. Merupakan tanaman semak, tanaman semusim, dengan } \\
\text { tinggi sekitar } 20-60 \mathrm{~cm} \text {. } \\
\text { b. Batang: bulat licin/basah, tidak berambut, diameter sekitar } \\
3 \mathrm{~mm} \text {, berwarna hijau dengan tinggi kurang dari } 50 \mathrm{~cm} \text {. } \\
\text { c. Daun: menyirip genap setiap tangkai daun terdiri dari daun } \\
\text { majemuk berukuran kecil dan lonjong. Anak daun } \\
\text { berjumlah sekitar } 15-24 \text { lembar, berwarna hijau, bentuk } \\
\text { bulat telur, panjang } 1,5 \mathrm{~cm} \text { dan lebar } 7 \mathrm{~mm} \text {, tepi rata, ujung } \\
\text { tumpul, dan pangkal membulat. } \\
\text { d. Bunga: berwarna putih, tunggal, berada dekat dengan } \\
\text { tangkai anak daun, dan menghadap ke bawah. } \\
\text { e. Buah: kotak, bulat, diameter } 2 \mathrm{~mm} \text {, dan berwarna hijau } \\
\text { keunguan. } \\
\text { f. Biji: biji kecil, keras, dan berwarna coklat. } \\
\text { g. Tempat tumbuh: tumbuh liar di daerah tropis, di tempat } \\
\text { lembab dan berbatu pada dataran rendah hingga } \\
\text { ketinggian } 1000 \mathrm{~m} \text { diatas permukaan laut. Tumbuh di } \\
\text { sepanjang saluran air, semak-semak, di hutan, lading, } \\
\text { kebun atau pekarangan rumah. }\end{array}$ \\
\hline
\end{tabular}




\begin{tabular}{|c|c|c|}
\hline 3 & $\begin{array}{l}\text { Rumput Gritingan } \\
\text { (Cynodon dactylon) }\end{array}$ & $\begin{array}{l}\text { a. Memiliki terna berstolon, merumput dengan rimpang } \\
\text { menembus tanah sampai kedalaman } 1 \mathrm{~m} \text {. } \\
\text { b. Lamina melancip dan memita, berlapis lilin putih keabu- } \\
\text { abuan tipis di permukaan bawah, gundul pada permukaan } \\
\text { bagian atas. } \\
\text { c. Pelepah daun panjang, halus, berambut atau gundul, } \\
\text { liguna tampak jelas berupa cincin rambut-rambut putih. } \\
\text { d. Bunga tegak seperti tandan. } \\
\text { e. Bijinya membulat telur, kuning sampai kemerahan. } \\
\text { f. Habitatnya tumbuh subur pada suhu diatas } 24^{0} \mathrm{C} \text { dan pada } \\
\text { tanah berdrainase baik tetapi toleran terhadap banjir yang } \\
\text { berkepanjangan, ph optimal diatas } 5,5 \text {. Toleran terhadap } \\
\text { kesuburan tanah yang rendah tapi tidak toleran terhadap } \\
\text { naungan. } \\
\text { g. Penyebarannya selain dari akar yang dapat membuat } \\
\text { rimpang dengan cepat juga melalui buah dan } \\
\text { penyebarannya meluas. }\end{array}$ \\
\hline 4 & $\begin{array}{l}\text { Rumput Teki } \\
\text { (Cyperus kyllingia) }\end{array}$ & $\begin{array}{l}\text { a. Akar: memiliki rimpang (umbi) menjalar, berbentuk kerucut } \\
\text { yang besar pada pangkal, kadang melekuk, berwarna } \\
\text { coklat, berambut halus dengan diameter sekitar } 5-10 \mathrm{~mm} \text {. } \\
\text { b. Batang: berbentuk segitiga, padat, licin, tumpul, } \\
\text { berdiameter } 1-1,5 \mathrm{~mm} \text { dengan panjang } 5-45 \mathrm{~cm} \text {. } \\
\text { c. Daun: terdiri dari } 4-10 \text { helai berjejal pada pangkal batang } \\
\text { membentuk roset akar dengan pelepah daun tertutup } \\
\text { tanah, helaian daun berbangun pita, bertulang sejajar, tepi } \\
\text { rata, permukaan atas berwarna hijau mengkilap dengan } \\
\text { panjang sekitar } 10-20 \mathrm{~cm} \text { dan lebar } 2-6 \mathrm{~mm} \text {. } \\
\text { d. Bunga: berbentuk bulir dengan 3-10 bulir kecil yang } \\
\text { mempunyai 8-25 bulir bunga yang berkumpul membentuk } \\
\text { paying dengan warna kuning/coklat kekuningan. } \\
\text { e. Buah: kecil, berbentuk memanjang sampai bulat telur. } \\
\text { f. Habitat: tumbuh liar di tempat terbuka/sedikit terlindung } \\
\text { dari sinar matahari dan berada di ketinggian 1-1000 dpl. }\end{array}$ \\
\hline 5 & $\begin{array}{l}\text { Kantung Semar } \\
\text { (Nepenthes) }\end{array}$ & $\begin{array}{l}\text { a. Tumbuhan ini bisa tumbuh mencapai tinggi } 15-20 \mathrm{~m} \text {. } \\
\text { b. Pada ujung daun ada sulu yang berbentuk kantong, yang } \\
\text { befungsi sebagai perangkap yang dipakai untuk } \\
\text { mengonsumsi mangsanya. } \\
\text { c. Memiliki tiga jenis wujud kantong yaitu: kantong atas yang } \\
\text { berupa corong yang tak memiliki sayap dan warna dengan } \\
\text { sisi sulur menghadap ke belakang, kantong bawah yang } \\
\text { umumnya tergelak diatas tanah yang memiliki cairan enzim } \\
\text { dan memiliki sayap, dan kantong roset yang mempunyai } \\
\text { wujud sama dengan kantong bawah namun tumbuhnya di } \\
\text { bagian daun } \\
\text { d. Berdasarkan tempat penyebarannya memiliki 2(dua) tipe } \\
\text { yaitu yang hidup di dataran tinggi dan dataran rendah. } \\
\text { e. Tumbuh di area yang teduh, di tempat yang terbuka, } \\
\text { namun ada sebagian yang dapat tumbuh pada tanah } \\
\text { dengan kandungan logam berat. }\end{array}$ \\
\hline
\end{tabular}


Tabel 3. Keanekaragaman Fauna yang Teridentifikasi

\begin{tabular}{|c|c|c|}
\hline No & Nama / Nama Latin & Identifikasi \\
\hline 1 & $\begin{array}{l}\text { Semut Hitam } \\
\text { (Lasius fuliginosus) }\end{array}$ & $\begin{array}{l}\text { a. Tubuh terdiri dari tiga bagian: kepala, dada, dan perut. } \\
\text { b. Kepala semut dilengkapi dua antenna, sepasang rahang, } \\
\text { dan mata semut. } \\
\text { c. Dada semut dilengkapi dengan tiga kaki kokoh dan } \\
\text { depasang sayap. } \\
\text { d. Bagian ujung belakang perut semut dilengkapi dengan } \\
\text { sengat sebagai alat perlindungan diri. } \\
\text { e. Mengalami metamorfosis sempurna }\end{array}$ \\
\hline 2 & $\begin{array}{l}\text { Bapak pucung/red cotton } \\
\text { bug } \\
\text { (Dysdercus cingulatus) }\end{array}$ & $\begin{array}{l}\text { a. Badan: berwarna merah dengan panjang } 11-17 \mathrm{~mm} \text { dan } \\
\text { lebar } 4,5 \mathrm{~mm} \text {. Di belakang kepala dan perut ada garis putih } \\
\text { dan hitam. } \\
\text { b. Pada sayapnya yang berwarna coklat terdapat sepasang } \\
\text { bercak hitam, nimfanya berwarna merah cerah dan hidup } \\
\text { berkelompok. } \\
\text { c. Telur: biasanya diletakkan dibawah tanaman inang atau } \\
\text { ditempat yang terlindung pada sebuah lubang kecil. } \\
\text { Lubang tersebut kemudian ditutup dengan butiran tanah. } \\
\text { Jumlah telur sekitar } 100 \text { butir. Untuk perkembangannya, } \\
\text { telur perlu kelembaban yang tinggi. Jika keadaan kering, } \\
\text { telur akan mati. Telur menetas dalam } 5 \text { hari pada } \\
\text { suhu27 } 27^{\circ} \mathrm{C} \text {. }\end{array}$ \\
\hline 3 & $\begin{array}{l}\text { Lalat } \\
\text { (Musca domestica) }\end{array}$ & $\begin{array}{l}\text { a. Mempunyai sepasang sayap asli serta sepasang sayap } \\
\text { kecil yang digunakan untuk menjaga stabilitas saat terbang } \\
\text { b. Memiliki mata majemuk yang terdiri dari ribuan lensa yang } \\
\text { sangat peka terhadap gerakan disekitarnya }\end{array}$ \\
\hline 4 & $\begin{array}{l}\text { Belalang } \\
\text { (Valanga Nigricornis) }\end{array}$ & $\begin{array}{l}\text { a. Memiliki antena yang lebih pendek dari tubuhnya. } \\
\text { b. Memiliki dua buah mata yang majemuk } \\
\text { c. Memiliki dua pasang sayap dimana sayap depan lebih } \\
\text { sempit dibandingkan sayap belakang dengan vena yang } \\
\text { teratur, pada waktu istirahat sayap belakang melipat di } \\
\text { bawah sayap depan. } \\
\text { d. Memiliki tiga pasang kaki dengan kaki belakang yang } \\
\text { ukurannya lebih besar. } \\
\text { e. Pada ruas pertama abdomen terdapat membran alat } \\
\text { pendengar yang disebut tympanum. }\end{array}$ \\
\hline
\end{tabular}

Tahap 4

Setelah pengidetifikasian keanekaragaman hayati, analisa data berikutnya yang dilakukan adalah untuk mengidentifikasi bagian bawah permukaan. Data yang diperlukan adalah data koordinat masingmasing titik dan data potensial yang terukur. Berikut disajikan tabel data hasil pengukuran potensial yang terukur. 
Tabel 4. Data Hasil Pengukuran Potensial

\begin{tabular}{|c|c|c|c|c|c|}
\hline No & TITIK & SOUTH & EAST & ELEVATION & $\begin{array}{c}\text { POTENSIAL } \\
(\mathrm{mV})\end{array}$ \\
\hline 1 & 1.1 & 02,28104 & 113,90846 & 100 & 1.2 \\
\hline 2 & 2.1 & 02,28114 & 113,90846 & 104 & 0.8 \\
\hline 3 & 3.1 & 02,28124 & 113,90846 & 93 & 0.6 \\
\hline 4 & 4.1 & 02,28134 & 113,90843 & 92 & 1.2 \\
\hline 5 & 5.1 & 02,28144 & 113,90843 & 87 & 1.3 \\
\hline 6 & 6.1 & 02,28154 & 113,90843 & 90 & 0.7 \\
\hline 7 & 7.1 & 02,28164 & 113,90843 & 91 & 0.7 \\
\hline 8 & 8.1 & 02,28174 & 113,90843 & 89 & 0.5 \\
\hline 9 & 9.1 & 02,28184 & 113,90843 & 86 & 2 \\
\hline 10 & 10.1 & 02,28194 & 113,90843 & 90 & 2 \\
\hline 11 & 1.2 & 02,28103 & 113,90855 & 103 & 2.8 \\
\hline 12 & 2.2 & 02,28113 & 113,90852 & 102 & 2.1 \\
\hline 13 & 3.2 & 02,28123 & 113,90850 & 97 & 0.8 \\
\hline 14 & 4.2 & 02,28133 & 113,90849 & 92 & 0.7 \\
\hline 15 & 5.2 & 02,28143 & 113,90849 & 85 & 0.9 \\
\hline 16 & 6.2 & 02,28153 & 113,90849 & 97 & 1.1 \\
\hline 17 & 7.2 & 02,28163 & 113,90849 & 98 & 1.4 \\
\hline 18 & 8.2 & 02,28173 & 113,90849 & 97 & 0.8 \\
\hline 19 & 9.2 & 02,28183 & 113,90849 & 100 & 1.5 \\
\hline 20 & 10.2 & 02,28193 & 113,90849 & 101 & 1.2 \\
\hline 21 & 1.3 & 02,28102 & 113,90855 & 99 & 1.4 \\
\hline 22 & 2.3 & 02,28112 & 113,90855 & 98 & 1.1 \\
\hline 23 & 3.3 & 02,28122 & 113,90855 & 98 & 1.3 \\
\hline 24 & 4.3 & 02,28132 & 113,90855 & 95 & 0.7 \\
\hline 25 & 5.3 & 02,28142 & 113,90855 & 97 & 0.8 \\
\hline 26 & 6.3 & 02,28152 & 113,90855 & 97 & 0.9 \\
\hline 27 & 7.3 & 02,28162 & 113,90855 & 98 & 1 \\
\hline 28 & 8.3 & 02,28172 & 113,90855 & 99 & 1.2 \\
\hline 29 & 9.3 & 02,28182 & 113,90855 & 99 & 1.3 \\
\hline 30 & 10.3 & 02,28192 & 113,90855 & 100 & 1.4 \\
\hline 31 & 1.4 & 02,28101 & 113,90861 & 90 & 1.4 \\
\hline 32 & 2.4 & 02,28111 & 113,90861 & 88 & 1 \\
\hline 33 & 3.4 & 02,28121 & 113,90861 & 91 & 1.4 \\
\hline 34 & 4.4 & 02,28131 & 113,90861 & 87 & 0.8 \\
\hline 35 & 5.4 & 02,28141 & 113,90861 & 89 & 0.9 \\
\hline 36 & 6.4 & 02,28151 & 113,90861 & 90 & 1 \\
\hline 37 & 7.4 & 02,28161 & 113,90861 & 91 & 1 \\
\hline & & & & & \\
\hline 19 & & & 97 \\
\hline
\end{tabular}




\begin{tabular}{|c|c|c|c|c|c|}
\hline 38 & 8.4 & 02,28171 & 113,90861 & 96 & 1.2 \\
\hline 39 & 9.4 & 02,28181 & 113,90861 & 95 & 1.2 \\
\hline 40 & 10.4 & 02,28191 & 113,90861 & 90 & 1.4 \\
\hline 41 & 1.5 & 02,28100 & 113,90867 & 90 & 0.9 \\
\hline 42 & 2.5 & 02,28110 & 113,90867 & 90 & 1.6 \\
\hline 43 & 3.5 & 02,28120 & 113,90867 & 82 & 1.9 \\
\hline 44 & 4.5 & 02,28130 & 113,90867 & 90 & 1.6 \\
\hline 45 & 5.5 & 02,28140 & 113,90867 & 90 & 1 \\
\hline 46 & 6.5 & 02,28150 & 113,90867 & 93 & 1.3 \\
\hline 47 & 7.5 & 02,28160 & 113,90867 & 90 & 1.5 \\
\hline 48 & 8.5 & 02,28170 & 113,90867 & 90 & 1.7 \\
\hline 49 & 9.5 & 02,28180 & 113,90867 & 93 & 1.9 \\
\hline 50 & 10.5 & 02,28190 & 113,90867 & 90 & 1.8 \\
\hline 51 & 1.6 & 02,28099 & 113,90872 & 87 & 1 \\
\hline 52 & 2.6 & 02,28109 & 113,90872 & 87 & 1.5 \\
\hline 53 & 3.6 & 02,28119 & 113,90872 & 87 & 1.4 \\
\hline 54 & 4.6 & 02,28129 & 113,90872 & 85 & 1 \\
\hline 55 & 5.6 & 02,28139 & 113,90872 & 87 & 0.8 \\
\hline 56 & 6.6 & 02,28149 & 113,90872 & 87 & 0.7 \\
\hline 57 & 7.6 & 02,28159 & 113,90872 & 87 & 0.9 \\
\hline 58 & 8.6 & 02,28169 & 113,90872 & 83 & 2 \\
\hline 59 & 9.6 & 02,28179 & 113,90872 & 87 & 1.8 \\
\hline 60 & 10.6 & 02,28189 & 113,90872 & 87 & 1.7 \\
\hline 61 & 1.7 & 02,28098 & 113,90878 & 86 & 2 \\
\hline 62 & 2.7 & 02,28108 & 113,90878 & 86 & 2.1 \\
\hline 63 & 3.7 & 02,28118 & 113,90878 & 86 & 2.4 \\
\hline 64 & 4.7 & 02,28128 & 113,90878 & 83 & 2 \\
\hline 65 & 5.7 & 02,28138 & 113,90878 & 86 & 1.9 \\
\hline 66 & 6.7 & 02,28148 & 113,90878 & 86 & 1 \\
\hline 67 & 7.7 & 02,28158 & 113,90878 & 86 & 0.8 \\
\hline 68 & 8.7 & 02,28168 & 113,90878 & 85 & 0.5 \\
\hline 69 & 9.7 & 02,28178 & 113,90878 & 86 & 0.7 \\
\hline 70 & 10.7 & 02,28188 & 113,90878 & 86 & 1 \\
\hline 71 & 1.8 & 02,28097 & 113,90884 & 83 & 1.5 \\
\hline 72 & 2.8 & 02,28107 & 113,90884 & 83 & 1.3 \\
\hline 73 & 3.8 & 02,28117 & 113,90884 & 84 & 1.5 \\
\hline 74 & 4.8 & 02,28127 & 113,90884 & 83 & 1.5 \\
\hline 75 & 5.8 & 02,28137 & 113,90884 & 83 & 1.4 \\
\hline 76 & 6.8 & 02,28147 & 113,90884 & 83 & 1.3 \\
\hline 77 & 7.8 & 02,28157 & 113,90884 & 85 & 1 \\
\hline 78 & 8.8 & 02,28167 & 113,90884 & 83 & 1 \\
\hline 79 & 9.8 & 02,28177 & 113,90884 & 83 & 1 \\
\hline & & & & & \\
\hline
\end{tabular}




\begin{tabular}{|c|c|c|c|c|c|}
80 & 10.8 & 02,28187 & 113,90884 & 80 & 1.1 \\
\hline 81 & 1.9 & 02,28096 & 113,90890 & 82 & 1.4 \\
\hline 82 & 2.9 & 02,28106 & 113,90890 & 82 & 1.3 \\
\hline 83 & 3.9 & 02,28116 & 113,90890 & 83 & 1.1 \\
\hline 84 & 4.9 & 02,28126 & 113,90890 & 82 & 0.8 \\
\hline 85 & 5.9 & 02,28136 & 113,90890 & 83 & 0.5 \\
\hline 86 & 6.9 & 02,28146 & 113,90890 & 82 & 0.7 \\
\hline 87 & 7.9 & 02,28156 & 113,90890 & 84 & 0.7 \\
\hline 88 & 8.9 & 02,28166 & 113,90890 & 82 & 0.8 \\
\hline 89 & 9.9 & 02,28176 & 113,90890 & 80 & 0.9 \\
\hline 90 & 10.9 & 02,28186 & 113,90890 & 82 & 1 \\
\hline 91 & 1.10 & 02,28095 & 113,90896 & 80 & 1 \\
\hline 92 & 2.10 & 02,28105 & 113,90896 & 80 & 1.3 \\
\hline 93 & 3.10 & 02,28115 & 113,90896 & 79 & 1.7 \\
\hline 94 & 4.10 & 02,28125 & 113,90896 & 80 & 1.9 \\
\hline 95 & 5.10 & 02,28135 & 113,90896 & 80 & 2 \\
\hline 96 & 6.10 & 02,28145 & 113,90896 & 81 & 2 \\
\hline 97 & 7.10 & 02,28155 & 113,90896 & 80 & 1.8 \\
\hline 98 & 8.10 & 02,28165 & 113,90896 & 80 & 2 \\
\hline 99 & 9.10 & 02,28175 & 113,90896 & 81 & 2 \\
\hline 100 & 10.10 & 02,28185 & 113,90896 & 80 & 1.7 \\
\hline & & & & & \\
\hline
\end{tabular}

Gambar 3. Diagram Garis Data Potensial

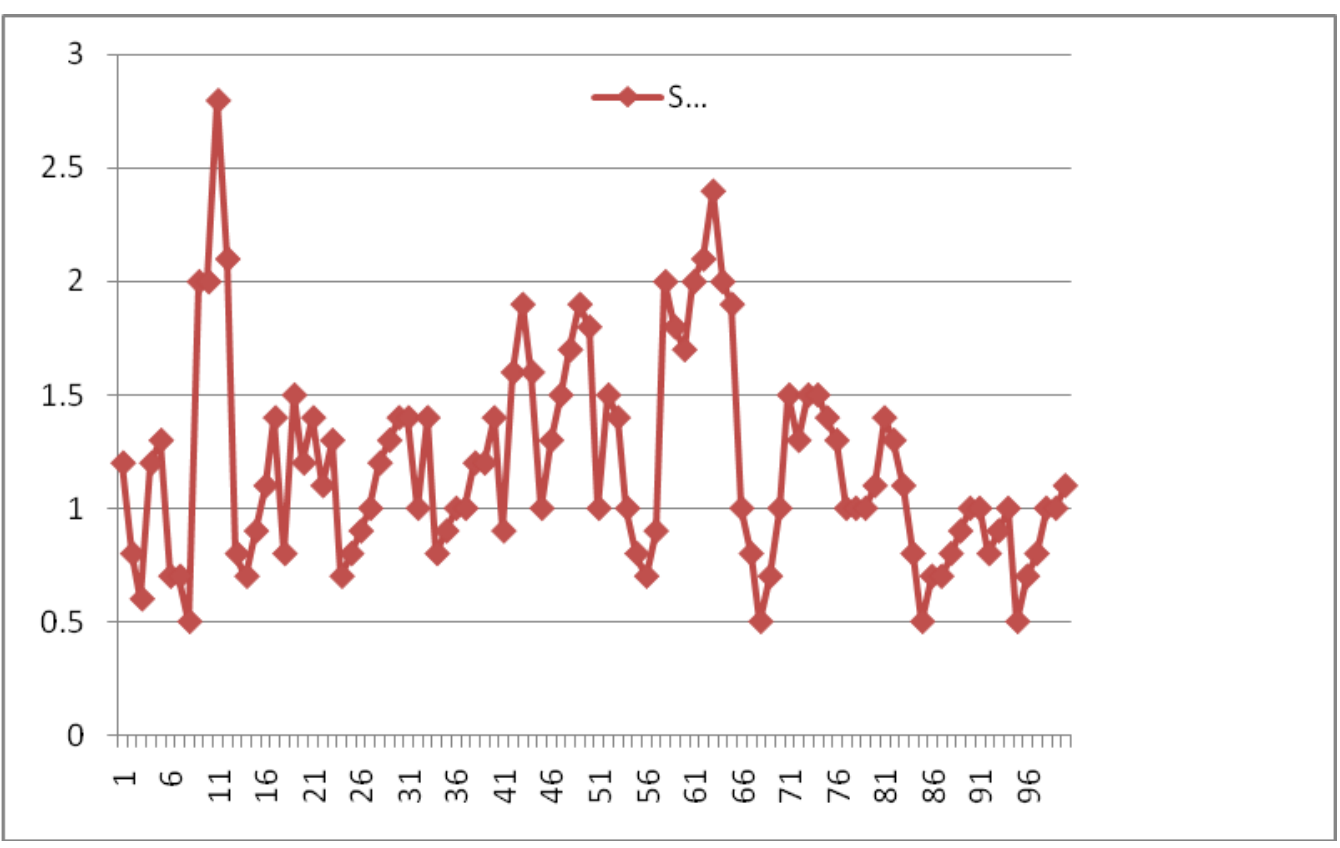


Setelah data potensial dituangkan dalam bentuk diagram garis, maka selanjutnya adalah analisa data dengan menggunakan Surfer 8 untuk mendapatkan peta kontur bawah permukaan pada lokasi penelitian seperti yang ditunjukkan gambar 4

\section{Tahap 5}

Hasil interpretasi data tentang keanekaragaman hayati dan pemetaan bawah tanah dituangkan dalam media objek pembelajaran. Sampel yang dijadikan sebagai media objek untuk keanekaragaman hayati adalah kantung semar. Alas an jenis flora tersebut dijadikan media karena jenis flora tersebut merupakan salah satu tanaman khas yang dijumpai di daerah penelitian. Jenis flora dan fauna lainnya dituangkan dalam media foto sehingga lebih efektif digunakan saat pembelajaran. Pemetaan bawah tanah yang teramati dituangkan dalam media gambar, dikarenakan anomali yang diharapkan oleh peniliti belum ditemukan pada peta kontur yang ada.

Diduga, bahwa potensial diri yang terukur ditimbulkan oleh:

1. Adanya perbedaan konsentrasi ion pada medium atau pelapisan tanah. Misalnya antara lapisan pasir dan lempung, atau antara medium yang mengandung air tawar dan air asin.

2. Adanya aliran zat cair (air tanah) dalam pelapisan tanah. Air dalam tanah banyak mengandung ion, aliran ion tersebut yang menyebabkan timbulnya potensial di permukaan tanah.

3. Adanya kandungan mineral yang diperkirakan berada di posisi $2,3-2,35^{\circ}$ LS dan $113,905^{\circ}$ BT berupa senyawa sulfida.
Hasil interpretasi inilah yang dapat dijadikan sebagai informasi awal adanya kandungan mineral dibawah permukaan tanah di lokasi penelitian. Untuk mengetahui lebih detail jenis mineral sulfida yang terkandung didalamnya, kita bisa menggunakan metode lainnya.

\section{KESIMPULAN}

1. Hasil penelitian yang didapat bahwa keanekaragaman hayati yang terdapat di Kampus Terpadu UM Palangkaraya didominasi oleh tumbuhan: kantung semar, karamunting, dan rumput teki untuk jenis floranya. Jenis fauna yang mendominasi adalah semut hitam.

2. Data potensial listrik yang telah dianalisa menunjukkan bahwa pemetaan lapisan bawah permukaan memiliki anomali berupa bahan galian berupa mineral sulfide yang berada di posisi $2,3-2,35^{\circ}$ LS dan $113,905^{\circ}$ BT.

\section{DAFTAR PUSTAKA}

Martiyono, 2012. Perencanaan Pembelajaran Suatu Pendekatan Praktis Berdasarkan KTSP Termasuk Model Tematik. Yogyakarta: Aswaja Pressindo

Santoso, Djoko. 2002. Pengantar Teknik Geofisika. Bandung: Penerbit ITB Bandung

Sudiartono. 2001. Teori dan Aplikasi Metode SP (Potensial Diri). Yogyakarta: Laboratorium Geofisika Fakultas MIPA UGM

Suwarno. 2009. Panduan Pembelajaran Biologi: Untuk SMA Kelas $X$. Jakarta: Pusat Perbukuan Departemen Pendidikan Nasional

Tim Pengembang MKDP Kurikulum dan Pembelajaran. 2011. Kurikulum dan Pembelajaran. Jakarta: PT. Rajagrafindo Persada 

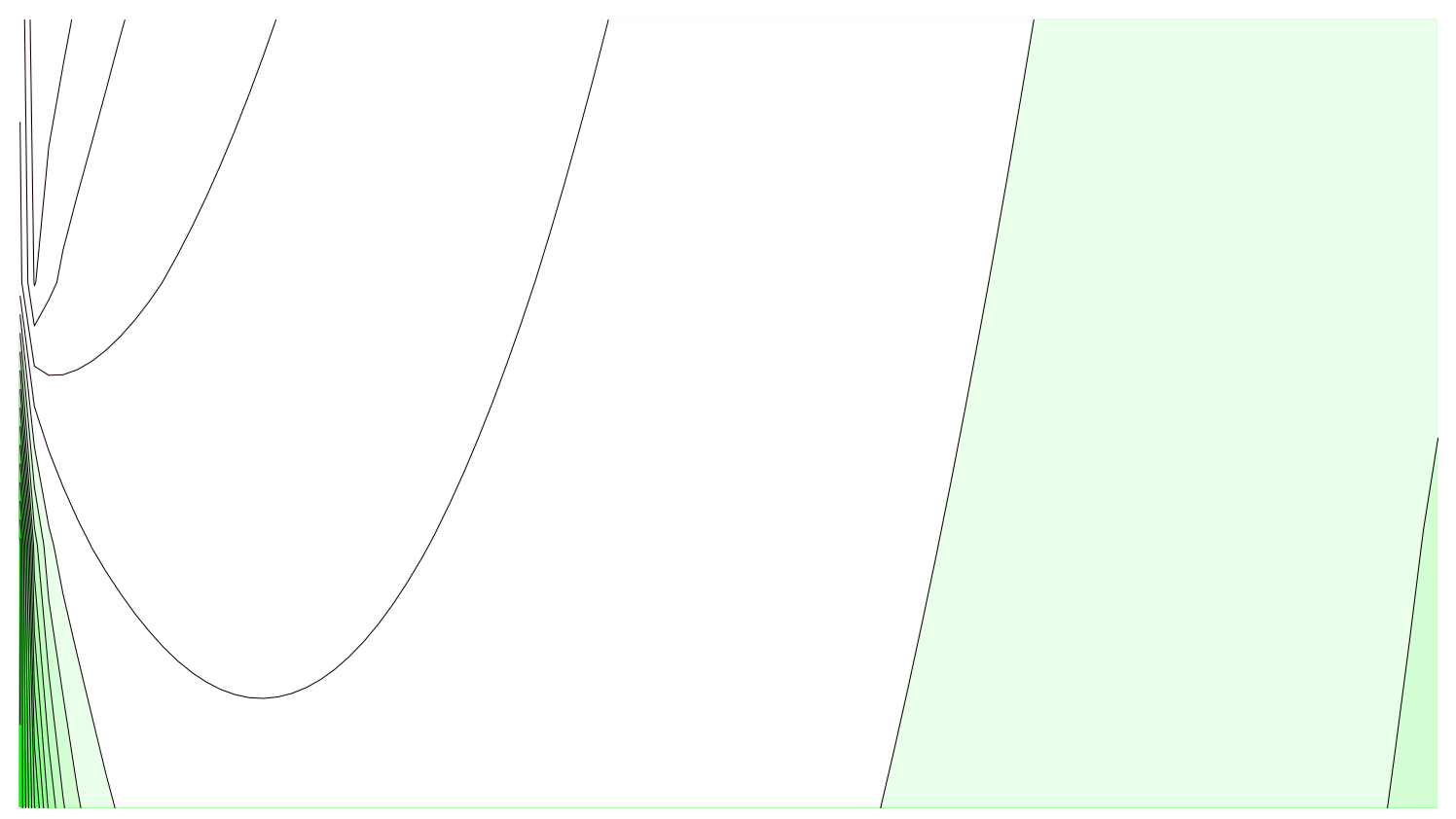

Gambar 4. Peta Kontur Bawah Permukaan

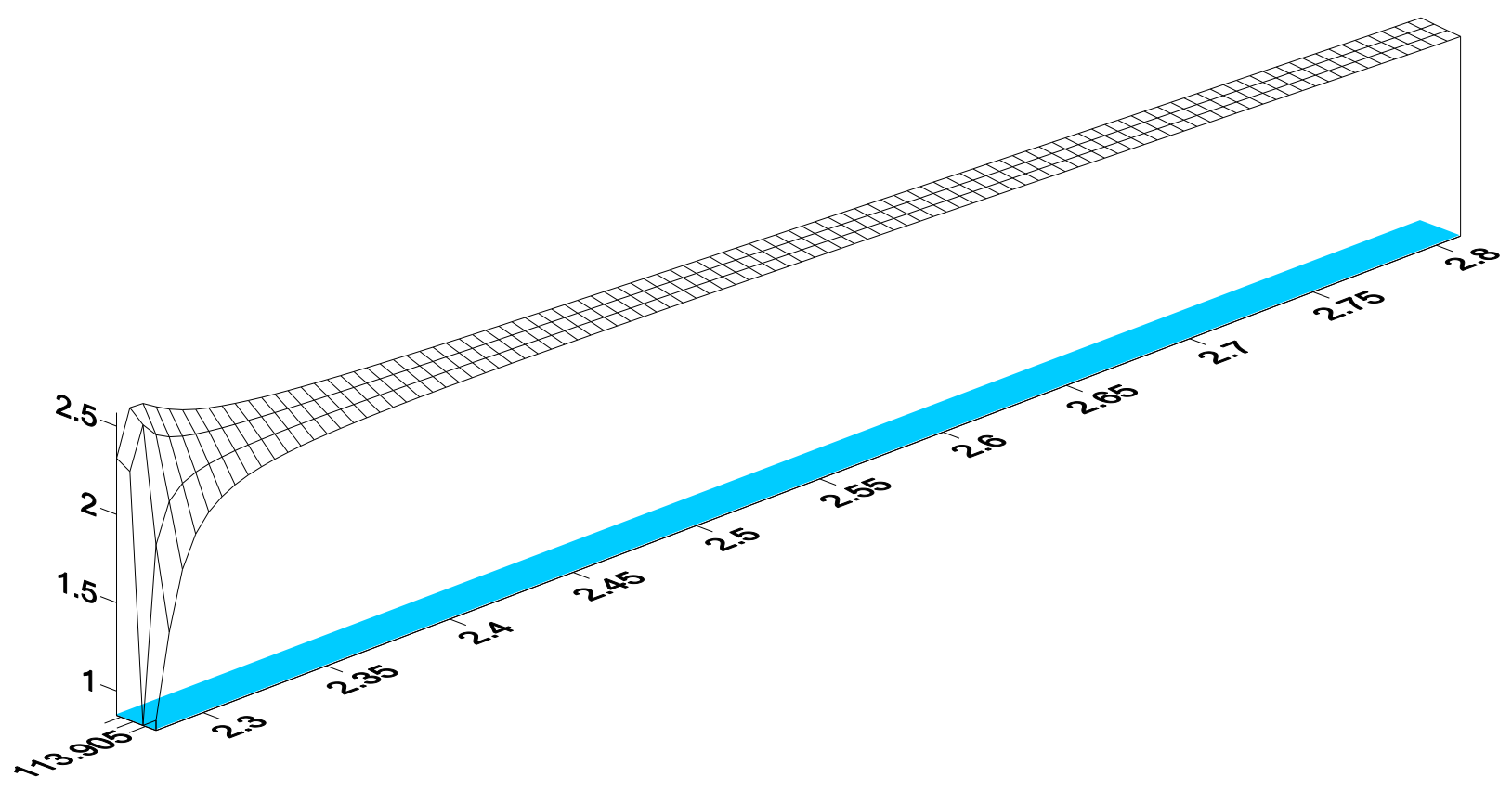

Gambar 5. Wireframe Map 